\title{
STATISTICAL EVIDENCE AND SUDDEN INFANT DEATH SYNDROME
}

\author{
Alexander Fiifi Ghartey ${ }^{1}$ and Michael William Stockdale ${ }^{2}$
}

\begin{abstract}
tatistical evidence is one of the prima facie tools used in the courtroom in common law jurisdictions. This paper is a case study aimed at describing the role of expert statistical evidence and how it influenced the outcome of the Sally Clark case. Sally Clark, a solicitor by profession, who was wrongly convicted and imprisoned by the Chester Crown Court in England in 1999 for the alleged murder of her two children. The prosecution's expert witness Professor Sir Roy Meadow, a consultant paediatrician, claimed in his statistical evidence that "the probability of two sudden infant death syndrome cases (SIDS) in one family matching the profile of the appellant was 1 in 73 million." Though upon appeal the Court of Appeal (Criminal Division) quashed the appellant's conviction in 2003, it brought to the fore the application of statistics in the courtroom and its overall impact on the justice system. It is revealed that statistical evidence should not be used to establish the truth of an ultimate issue with scientific certainty. Expert witnesses should not adduce evidence recklessly. The use of any far-reaching statistics as evidence requires the services of experts with competence in medical statistics. The criminal justice system has a huge task of exposing true child abusers. But the socioeconomic cost of wrongful conviction of accused parents of SIDS cases is immense. Tragically, Sally Clark never came to terms with her wrongful conviction and in 2007 drank herself to death.
\end{abstract}

\footnotetext{
* This paper is an extract from the Author's thesis presented to the University of Northumbria, Law School, Newcastle-Upon-Tyne, England and was awarded the LLM (Medical Law) degree in 2008. The author acknowledges the inputs directly or indirectly of all the lecturers of the Law School of the University.

1 University of Cape Coast, Department of Population and Health, Cape Coast, Ghana

2 Professor of Law, University of Northumbria, Law School, Newcastle-Upon-Tyne, England
} 


\section{Introduction}

Statistical evidence is one of the prima facie tools for litigating parties in criminal and civil trials in common law jurisdictions. Though the general principle of evidence is that witnesses are to testify only to fact known to them, over the course of time, the courts have encountered cases that require analysis and explanations by expert witnesses who have scientific or specialized knowledge or experience in matters in issue. Scientific, mathematical or statistical evidence may not normally be within the purview of the juror or even the judge's knowledge. It is humanly impossible for the judge or the juror to be knowledgeable in all specialized fields and therefore the need for expert evidence in medico-legal cases. ${ }^{3}$ However in the 1990's many parents, mainly mothers who had lost their children unexpectedly through cot deaths were wrongly imprisoned, some apparently on the basis of misleading expert evidence. Among cases of such wrongful convictions included Clark, ${ }^{4}$ Cannings $^{5}$ Anthony $^{6}$ and Patel. . In those cases, notably in Clark, expert witnesses particularly Professor Sir Roy Meadow ${ }^{8}$ gave 'misleading' statistical evidence.

Historically, both Jeremy Bentham and Lindley suggested that in order to accurately state facts and make precise inferences in court, evidence need to be quantified. In other words they need to be expressed in statistical form ${ }^{9}$. In 1782, Lord Mansfield stated that "men of science within their own science might give expert opinion on science"10. When in 1897 Oliver Wendell Holmes made the statement that 'the man of the future is the man of statistics and the master of economics, ${ }^{\prime 11}$ statistics as a discipline played a very insignificant role in court. It was largely unknown in legal proceedings. He emphasized the need for expert statistical evidence to be given by men of statistics within their own field for statistical evidence to be more useful to the administration of justice. The legal

\footnotetext{
3 Stockdale 2005

4 R v Sally Clark [2003] EWCA Crim 1020; 1200312 FCR 447

5 R v Cannings Angela [2004] EWCA Crim

$6 \mathrm{R}$ v Anthony Donna [2000] Court of Appeal, Criminal Division

7 R v Trupti Patel [2006] EWCA Crim 2689

8 Professor Meadow was born in Wigan, Lancashire in 1933, studied medicine at the University of Oxford and subsequently practised as a GP in Banbury. In 1970 he became a senior lecturer at the Leeds University and in 1980 he became a Professor of Paediatrics at the St. James University of Leeds Hospital. He was a former president of both the British Paediatric Association and the Royal College of Paediatrics and Child Health. Sir Roy's fame began in 1977 when he published a paper in the Lancet Medical Journal, a condition he called Munchausen Syndrome by Proxy (MSbP). For his 'services to child health', he was knighted in 1998.

9 Bernard Knight, 1982

10 Bentham: 1825 (refer Redmayne 2001 p.57; D.V. Lindley: Probability and the Law (1977).

11 Phillip Good, 2001
} 
storms of sudden infant death cases in England, particularly in Clark, brought to the fore the controversial role of expert witnesses in such cases, thus making them important medico-legal challenges in common law jurisdictions.

\section{Materials and Methods}

The purpose of this paper is to describe and explain the role of expert statistical evidence and how it influenced the outcome of the Sally Clark case. Relevant medico-legal issues are identified and discussed in relation to their impact on the justice system at common law. Legal sources including search engines, websites and literature searches in legal journals and documents were used or consulted. The method used is a descriptive analysis of the role of quantitative statistics applying essentially a document research approach. Expatiated below are the conceptual facts at the heart of this paper namely nature of evidence, theory of statistical methods and sudden infant death syndrome (SIDS).

\section{Nature and Essence of Evidence}

The primary role of the court is to hear the arguments and assess the evidence of the litigating parties who bear the evidential burden and pass a ruling on the issues of facts and law with the aim of arriving at a just conclusion. Evidence is "any material which has the potential to change the state of a fact-finder's belief with respect to any factual proposition which is to be decided and which is in dispute..." ${ }^{12}$ It is a re-construction of a given past event. The use of evidence in court is on the basis that current human knowledge of past events can be made possible and that the use of evidence is the best possible way of achieving that knowledge and establishing the probability of the occurrence of an event. Evidence must be relevant and admissible in order for a court to receive it. Irrelevant evidence is prima facie inadmissible because it is deemed not to carry the necessary evidential weight. ${ }^{13}$ An expert witness is "a person qualified to give an opinion on a particular matter [before a court] within his or her own field of expertise."14 Expert evidence, and for that matter expert statistical evidence is primarily an opinion evidence, a contentious area of the rule of evidence. The role of any expert witness is to give expert evidence in court in order that the court may reach just and fair conclusions. In principle, unlike facts, opinion evidence may not be admissible in court to prove the truth of a matter. This is because opinion is inference-based, derived from subjective perceptions and beliefs. Opinion evidence has the potential of being relevant or could even mislead the court. By definition the ultimate issue principle is one of the

12 Murphy 2005

13 Moenssens et al, 1995

14 Hill, Wood and Fine (2005 p.253) 
opinion evidence rules. It seeks to limit the statement of facts to expert witnesses and the drawing of inferences from facts to the tribunal of fact, the latter being the jury in criminal cases and the judge. In civil proceedings witnesses are generally not permitted under the rule to make inferences from facts, or make speculations with respect to the causes of the facts or pronounce judgement about them. ${ }^{15}$ This effectively prevents the usurpation of the functions of the jury and further lays the foundation for the hearsay rule which prevents a witness from "giving evidence of a statement made by another person... if the purpose of adducing the statement is as evidence of the truth of its factual content" 16 . Expert evidence may be adduced in various specialized medical fields such as forensic science, pathology, clinical medicine, psychiatry, epidemiology and pediatrics.

\section{Sudden Infant Death Syndrome}

Sudden infant death syndrome is the generic term for the sudden and unexpected death of a seemingly healthy child under one year of age. The US National Institute of Child Health, defined SIDS (also called cot or crib death), in 1991 as a "sudden death of an infant under one year of age, which remains unexplained after a thorough investigation, including performance of complete autopsy, examination of the death scene, and review of the clinical history"17 A key feature of cases of SIDS is that the death occurs in a seemingly healthy baby during sleep and that no cause of death can be identified after thorough case investigation including autopsy. Risk factors for SIDS identified through epidemiological studies demonstrate a strong correlation between infant sleeping positions, sleeping environment and SIDS. ${ }^{18}$ SIDS became a registrable cause of mortality in England and Wales in 1971. In Ghana however statistics on SIDS as a cause of infant deaths is at best scarce. Studies on hospital-based data shows that the main causes of infant mortality in Ghana are malaria, severe anemia, and neonatal sepsis. ${ }^{19}$ It must be noted that historically SIDS is an ancient tragedy. ${ }^{20}$

\section{Damn Lies and Statistics}

Expert statistical opinion may be based on statistical information, published or

\footnotetext{
15 Stockdale \& McAlhone (1993)

16 Stockdale (n 14) 1

17 The International Statistical Classification of Diseases and Related Health Problems 10th Revision (ICD-10)-WHO Version for 2016 classifies SIDS with the code R95.

18 Polina Gelfer \& Michelle Tatum, Sudden Infant Death Syndrome (Journal of Pediatric Health Care, Volume 28, Issue 5) 470-474.

19 Awolu Adam, Gender Differentials and Disease-Specific Cause of Infant Mortality: A Case Study in an Urban Hospital in Accra, Ghana (African Journal of Reproductive Health June 2016; 20 (2): 104)

20 Biblical record of the Judgement of Solomon in Kings I Chapter 3.
} 
unpublished. ${ }^{21}$ Sources of statistics may include professional journals, research papers or experiments, materials written by professional peers and the general body of knowledge that fall within the scope of the relevant expertise of the expert witness. An expert statistical witness may be said to be an expert witness qualified to adduce in court expert evidence involving the principles of statistics and probability by virtue of his knowledge-base and competence derived from his training, qualifications and professional experience.

Traditionally, statistics is a "scientific methods for collecting, organizing, summarizing, presenting and analyzing data as well as with drawing valid conclusions and making reasonable decisions on the basis of such analysis"22 Statistics as a discipline involves converting data into information that may be used in decision - making. Statistics may be quantitative (numbers) or prose (words) in form and nature. A number of reasons justify the use statistical methods in court. Statistics are by nature picturesque and precise in measurement. Their inherent measuring attribute provide a reasonable standard for comparison and for making inference and predictions. Furthermore, legal concepts such as 'balance of probabilities', 'more likely than not' and 'beyond a reasonable doubt' are all subject to statistical representation and interpretation. In practice statistics may be expressed in court by the application of the principles of probability, a measure of how confident and sure a person is about a proposition. It is an objective measure of the degree of belief in the truth of a hypothesis. In quantitative statistics, experts may express probability using mathematical symbolism namely statistical probability rules and theorems such as the Bayes Theorem ${ }^{23}$ and the Odds Ratio rule. ${ }^{24}$ On the other hand, qualitative or prose-based statistics involves the use of words such as possibly, probably, very probably, almost certainly and certainly may be used in lieu of quantitative statistical values. And they may lend themselves to quantitative interpretation. Statistics themselves could be imperfect, in that they could be bias, confusing, or even contentious. The uncertainties surrounding the subject, explain Mark Twain's famous statement in 1924 that "There are three kinds of lies: Lies, Damn Lies and Statistics." That notwithstanding there is a wide spectrum of disciplines including the medical sciences that may find the use of statistical evidence in court useful. Essentially, the methodology used in this case study is a descriptive analysis of the role of quantitative statistics in the Sally Clark case, the choice of which was by purposeful selection and the method used essentially a document research approach. ${ }^{25}$

21 Clark (n 4) 2

22 R v Abadom [1983] 1 WLR 126

23 Spiegel M.R 1992, p.1

24 People v Collins (1968) 438 P 2d 33

25 Bowling (2014 p.436-448) 


\section{Case Study: R v Sally Clark [2003] EWCA Crim 1020; 1200312 FCR 447}

The facts of the case is that a Chester Crown Court in England presided over by trial Judge Harrison and assisted by a jury, convicted Mrs. Sally Clark on 9 November 1999 for the alleged murder of her babies, Christopher and Harry when they were aged 11 and 8 weeks respectively. The 35-year-old Mrs. Clark, a solicitor by profession, lived in Winslow, Cheshire with her husband, Stephen Clark also a solicitor. They married in 1990, and had their first child Christopher on 26 September 1996. But despite being apparently healthy, the child died in the evening of 13 December 1996. A post-mortem carried out by a Crown pathologist, Dr. Alan Williams initially diagnosed the cause of death as a lower respiratory tract infection and thus treated it as a case of SIDS. The second child Harry born on 29 November 1997 also died on 26 January 1998. Dr. Williams performed the post-mortem and recorded the cause of death as non-accidental injury. He followed it up by altering the cause of death for Christopher as smothering. Subsequently Sally Clark was arrested on suspicion of the murder of both Christopher and Harry. Sally Clark denied the charge, and was strongly supported by her husband Steve. Interestingly, Sally gave birth to a third son in the course of the case.

Facts in issue that needed to be determined by the jury in the original trial were whether the death of the children were due to natural or unnatural causes and whether it was a case of SIDS or murder. Expert medical opinion for both parties was divided as to the cause of death. Whereas the prosecution suspected that the two deaths were unnatural and probably resulted from smothering, the defense' medical experts considered them unexplained natural deaths. The prosecution's expert witness Professor Roy Meadow, a consultant pediatrician, relying on a draft of Confidential Enquiry into Stillbirths and Deaths in Infancy (CESDI) report ${ }^{26}$ claimed that "the probability of two SIDS deaths in one family matching the profile of the appellant were 1 in 73 million." The likelihood of a possible SIDS incidence was therefore ruled out.

The defense argued the innocence of Sally Clark and maintained that the babies may have died from 'natural causes'. It questioned the reliability of the forensic pathologist Dr. Alan Williams' post-mortem diagnosis of cause of death and argued that it was unlikely that a man will blindly cover up for a wife who murders his children. The defense argued that there is greater inherent risk for a family that has experienced a SIDS death to experience another. But the jury on a 10/2 majority decision convicted the accused Sally Clark. Mrs. Clark subsequently appealed against her conviction. Among the five grounds for appeal submitted to the Court of Appeal was Prof Meadow's 1 to 73 million statistical

26 Principal author Professor Fleming of the Institute of the University of Bristol was commissioned by the Department of Health to write the report. 
evidence. On the basis of the circumstantial evidence against the appellant, the Court of Appeal, ${ }^{27}$ on $2^{\text {nd }}$ October 2000 ruled to affirm the conviction of Sally Clark. It considered the 'overwhelming' overall evidence against her as a proof of guilt but did not criticize the statistical evidence of Meadow except that it downplayed it as irrelevant and a mere 'sideshow'.

The Criminal Cases Review Commission (CRC) subsequently referred the case for a second appeal. On 29th January 2003, the Court of Appeal (Criminal Division) quashed the appellant's conviction. It had come to light that important microbiological evidence had not been disclosed at trial or to the prosecution. Dr. Alan Williams, the Crown forensic pathologist who performed the autopsy, had failed to disclose the results of medical tests which showed that at least one of Sally Clark's babies had died from a lethal bacterial infection called Staphylocuccus aureus, and not as a result of smothering as claimed by the prosecution. The Crown prosecution did not seek a retrial. Dr. Williams was later banned from Home Office pathology work or coroners' cases for three years.

Mrs. Clark's father (Frank Lockyer) made a formal complaint to the General Medical Council (GMC) alleging a serious professional misconduct charge against Professor Meadow, and following a sixteen-day hearing, he was found guilty of serious professional misconduct by the GMC's Fitness to Practice Panel (FPP) for his erroneous statistical evidence. Professor Meadow appealed to the High Court in line with section 40 of the Medical Act 1983. On 17th February 2006, the High Court reversed the erasure, overturning the serious professional misconduct verdict of the FPP; restored Professor Meadow to his original. The scope of the immunity for Professor Meadow included immunity from professional disciplinary action ${ }^{28}$ Upon appeal by the GMC, the Court of Appeal overturned the ruling of the High Court on immunity for expert witnesses from disciplinary action on a 2-1 majority decision. ${ }^{29}$ However, it affirmed the High Court ruling that Professor Meadow was not guilty of serious professional misconduct, though he had committed some professional misconduct. It also upheld the existing principle of expert witness immunity from civil suit. ${ }^{30}$ There were three main reasons provided for the landmark ruling in the GMC v Meadow case. It was to prevent a situation where expert witnesses were deterred from appearing in child abuse cases and speaking "freely and fearlessly" ${ }^{11}$ in the protection of children from abuse. The second consideration was that

27 Comprising Lord Justice Henry, Mrs Justice Bracewell and Mr Justice Richards

28 Meadow v General Medical Council [2006] EWHC 146 (Admin)

29 Lord Justice Auld and Lord Justice Thorpe in the majority and Master of the Rolls Sir Anthony Clarke dissenting.

30 General Medical Council v Meadow [2006] EWHC Civ 1390

31 Darker v Chief Constable of West Midlands [2001] 1 AC 435 
Professor Meadow was judged to have acted in good faith and did not intend to mislead the jury. Thirdly it was aimed at minimizing the tendency of parties who lose a case, from deliberately and unnecessarily prolonging the course of litigation in court. ${ }^{32}$

\section{Results and Discussion}

Professor Meadow adduced statistical evidence as a means of communicating to the jury his 'expert' opinion. This flawed statistical evidence expectedly got very wide news coverage in the English media. Meadow's 'flamboyant' statistical display appears to have distracted the jury from focusing its attention on the non-statistical evidence adduced. The misleading nature of the statistical evidence in Clark raises a number of collateral questions relating to how capable jurors and trial judges are in coping with complex statistical probability theorems in court and for that matter scientific principles; whether the use of statistical evidence really facilitate the courts' aim of reaching just and fair rulings and whether the misuse of statistics by an expert witness constitutes a serious professional misconduct. Professor Meadow applied an 'irrelevant' and 'prejudicial' probability multiplication rule using the odds ratio to calculate the risk of two infants dying in a family by chance. Professor Meadow arrived at his "one in 73 million" probability by mathematically squaring the chance of an affluent family suffering one cot death (one in 8,543). He had failed to consider genetic and environmental factors in his theory on the chances of a second infant mortality occurring in the same family.

It could be argued that Professor Meadow may have acted rightly by citing the source upon which his figure of 1 in 73,000,000 was based i.e. the draft CESDI report. Statistical evidence based on research findings by a reputable authority may be presumed authoritative evidence of a fact, unless it is reliably and logically contradicted by an opponent as a mere hearsay. The defense expert witnesses Professor Berry, a co-author of the CESDI report and the other pediatricians of the defense could have done more to draw the jury's attention to the flawed statistical evidence of Meadow and his deficient expertise in the use of statistics. They appeared to have accepted Meadow's statistical evidence. Besides, the jury's attention was not drawn by the trial judge that there was a looming prosecutor's fallacy either. As the final arbiter of evidence admissibility, the trial judge could have prevented Professor Meadow from straying outside the domain of his expertise. In the field of statistical probability he had little or no expertise. These shortcomings however did not justify Meadow's flawed statistical evidence. Though he may have acted in good faith, Prof. Meadow himself stated at the cross-examination that 'I don't like statistics, but l'm forced into their usefulness."

32 Roy v Prior [1971] AC 470 
Strangely, the first Court of Appeal considered that "there was an overwhelming case against the appellant at trial" albeit it conceded that the 73 million figure should have been treated as a 'distraction'. Interestingly, Meadow's misleading statistical evidence appears to have nothing technically to do with the success of the second appeal. Unlike in the first Appeal Court proceedings his statistical opinion was strongly criticized by the trial judge. Several peer experts including the Royal Statistical Society (RSS) giving evidence before the GMC rejected Professor Meadow's statistical evidence as having "no statistical basis". In the process Professor Meadow committed four fundamental statistical errors.

In applying the principle of odds ratio, Professor Meadow misunderstood and misapplied the multiplication rule of probability on the basis of statistically invalid assumption of independence between the two cot deaths in the same family. The appropriate probability principle that may have been statistically plausible is the conditional multiplication rule ${ }^{33}$ and not the ordinary multiplication rule. Prof. Meadow's second statistical error was his categorization of families into two classes by applying only three risk factors of SIDS namely smoking, income and age of mother although there were several known risk factors of SIDS deaths. ${ }^{34}$ He wrongly categorized the Clark family as a low-risk as far SIDS incidence was concerned and failed to recognize that individual families may have specific and unique genetic, environmental and socio-economic characteristics that could affect the health and well-being of the family including the vulnerable child. It is reasonable to expect that when a cot-death occurs in a given family, the probability of other cot-deaths in that family is likely to be greater than the group average estimate because of likely family predisposition. The population statistics of cot deaths only provided a broad bird's eye view of the incidence pattern in the population and cannot be valid when it is applied to any given individual population unit (family). One should not therefore infer an act of murder from them. Meadow's omission could also be described as a prosecutors' fallacy. Since the GMC's FPP and the Court of Appeal ruled that he acted without intending to mislead the jury, he most likely committed the prosecutors' fallacy out of ignorance. He adduced fallacious evidence and therefore could not be described as having the expertise to adduce statistical evidence in court. Yet he was adducing expert evidence in a criminal case in which the standard of proof was proof beyond all reasonable doubt.

33 The probability $(P)$ OF $2^{\text {nd }} \cot$ death $y$ given the first death $x$ is symbolically denoted $p(y / x)$. $P(x$ and $y)=$ $P(x) . P(y)$ is the invalid Meadow's probability application which should have been $P(x$ and $y)=P(x) \cdot P(y / x)$. Note that $P(y / x)$ is not known until it is studied empirically. (Refer Spiegel MR 1992) 34 Office for National Statistics Health Statistics Quarterly 27 autumn 2005; and Byard \& Krous (2001) 
Professor Meadow's expertise was in pediatric medicine. He was not a biostatistician. He was therefore competent to give expert opinion evidence in his own field as a pediatrician and not in the field of biostatistics. Ultimately, the decision as to Professor Meadow's competence to tender opinion statistical evidence was for the trial judge to make. The trial judge rightly cautioned the jury against the application of statistics in their verdict in his last day summing-up. Said he: "we do not convict people in these courts on statistics," But perhaps he should have applied the exclusionary rule earlier. It appears that the trial judge did not highlight the 73 million statistical evidence as a distraction probably because of the general reputation of Professor Sir Meadow. His achievements in the area of pediatrics had been acknowledged wide and near. Prof Meadow, was originally renowned for postulating what had become known as the 'Meadow's Law' namely, that "one sudden infant death is a tragedy, two is suspicious and three is murder, unless proven otherwise." His status as a renowned pediatrician may have added to the perceived strength and credibility of his statistical evidence. At the pinnacle of his career he had been knighted.

In an another case in 1993, The Meadow's Law had ironically been vindicated when Sir Meadow successfully brought expert evidence against a nurse Beverley Alit, ${ }^{35}$ accused of murdering four children and having harmed nine others. Beverley was convicted and sentenced to life imprisonment. In contrast the Meadow's Law played a significantly devastating role Clark. Technically, a verdict of guilty was returned on Sally Clark by the jury not on the basis of statistics. But the role of numbers in securing the verdict of the jury cannot be discounted or downplayed. The other reason why the jury may have put much weight on the Meadow's statistical evidence is the apparent mystic infallibility of numbers. The one in 73 million figures captured the headlines in the media thus having an instant and dramatic impact on the public, the jury probably not excluded. Sight must also not be lost of the fact that the Crown forensic pathologist, Dr. Alan Williams, who performed the post-mortem had failed to disclose the results of medical tests which showed that at least one of Sally Clark's babies had died from a lethal bacterial infection which may have also constituted a serious professional misconduct.

Another principle of interest in Clark relates to expert witness' immunity and accountability. In the GMC v Meadow ${ }^{36}$ case the Court of Appeal re-echoed Lord Justice Auld's statement in Darker: 'The whole point of the first public policy reason for the immunity is to encourage honest and well-meaning persons to assist justice even if dishonest and

35 Beverly Gale Alit worked at the Lincolnshire Clinic in England as a pediatric nurse. His method of lethal insulin dosing and whenever she failed, just suffocated the victim. According to one theory, he suffers from the Minhauzen syndrome and caused the pain to attract the attention of others.

36 GMC v Meadow [2006] EWCA Civ 1390 
malicious persons may on occasion benefit from the immunity.' At common law expert witnesses and by implication expert statistical witnesses don't enjoy absolute immunity though they enjoy immunity from civil suit. Even though immunity bars civil suits, an expert witness is not protected from contempt proceedings. He does not enjoy the right of immunity if he perverts the course of justice. ${ }^{37}$ Contempt or perjury proceedings may be brought against a bad expert witness if he gives willful and deceitful evidence. The criminal justice system may be shooting itself in the foot if it protects the expert witness from civil suit while at the same time it permits him to subvert the same administration of justice. Opinion evidence as a matter of personal judgement and adduced in good faith is not subject to perjury proceedings. ${ }^{38} \mathrm{An}$ incompetent expert witness may lose integrity and respect within his professional body and may come under ferocious criticisms by his peers.

Another issue of interest is the selection and the composition of the jury itself. For expert statistical evidence to achieve its ultimate aim of assisting the court to reach just conclusions, it is vital to ensure that the jury has the capacity to deal scrupulously with such evidence when they are adduced in court. The mode of selection of jury pools or panel is therefore an important factor for consideration. It is natural that one needs to be mathematically minded to grasp and assess the validity of complex statistical computations in court. In Sally Clark, the jury needed to assess the "relative likelihood of the deaths" under either SIDS or murder and not just how unlikely they are due to SIDS. The principle of random selection which itself is a sampling technique in the discipline of statistics, gives all qualified adult citizens roughly equal chance of being selected to serve on the jury. It may provide the courts with a jury that is representative of the community and any possible biases offsetting each other, making its final decisions products of diffused impartiality. However it appears that the procedure as it existed did not make provision for the caliber of jurors with the appropriate knowledge and skills to deal competently with scientific or statistical evidence. There are two possible ways of getting around this problem. A hybrid procedure involving random selection from a pool of adequately competent and qualified persons. Alternatively, the trial judge's summing up must serve to 'educate' the jury and to draw attention to the risk of prosecutor's fallacy in such cases. It appears that in high profile and complex proceedings it may be advantageous to define juror competence mainly in terms of qualifications, experience and proven expertise.

Prof Meadow was struck off the medical register by the GMC for serious professional misconduct. The GMC had a duty to protect public interest, maintain public confidence in

37 Roy v Prior [8] 30

38 Contempt of Court Act (1981) 
the medical profession and to declare and uphold proper standards of performance and conduct. However, public confidence in the medical profession and even the administration of justice may have been adversely affected as a result. The High Court and later the Court of Appeal however reversed this erasure and restored him to his original status. A contentious issue is the ruling by the Court of Appeal that Professor Meadow's statistical evidence in Clark did not constitute serious professional misconduct. The majority ruled that Professor Meadow's had committed 'misconduct' and not a serious professional misconduct. The argument that evidence not adduced in bad faith does not constitute a serious professional misconduct appears feeble. As Sir Anthony Clarke, MR noted in GMC v Meadow, Clark was a 'rare case in which a person should be held to be guilty of serious professional misconduct in the absence of bad faith'.

\section{Conclusion and the Way Forward}

The lesson learnt from Clark is that expert witnesses should not be allowed to give reckless evidence. They must offer explanations and reasons for their opinion, provide sources or evidence for the assumptions on which their opinions are based and must not adduce evidence outside their field of expertise. They must give evidence honestly and in good faith; and must not seek to mislead the court. The enormity of the overall impact of the statistical evidence in the Clark case on the jury, the English medical system and the common law cannot be over-emphasized. The courts cannot use theoretical statistical evidence to establish the truth of an ultimate issue with mathematical or scientific certainty. Statistics cannot and should not be the basis for conviction. To convict a defendant of murder requires taking all steps necessary not to convict the innocent. That notwithstanding the role of pediatricians and pathologists as medical experts in SIDS cases is inevitably important. But the use of any far-reaching statistics as evidence require that experts with competence in medical statistics adduce evidence. The expert witness owes a duty to himself to be aware of his duties, his responsibilities, his limitations as well as court procedures and practices. A good expert witness must exhibit the values of independence, objectivity and be manifestly non-dogmatic. An expert above all must recognize that his foremost duty is to help the court reach the correct conclusions. He has the ethical obligation to state any assumptions on which his opinion is based and to state in clear terms any issue that falls outside his expertise. The court also has a duty to ensure that only qualified experts adduce evidence as expert statistical witnesses. Statistical evidence should also not overshadow non-statistical evidence. Lay opinion should not be allowed to masquerade as expert opinion. Probably, the most qualified professionals to adduce the most reliable statistical evidence in SIDS cases are biostatisticians and epidemiologists. 
Professional bodies should encourage their members who are expert statistical witnesses to be refreshed in statistical probability theorems and how to adduce persuasive nonfallacious oral evidence in court. Since the average juror may not be statistics-literate it may be necessary for the judiciary to design statistics related educational programmes for judges and jurors. The more educated judges and jurors become in statistics the greater may be their ability to detect statistical fallacies and exercise the power of exclusionary discretion when it matters most. The curricula of law schools may also be designed to adequately incorporate the discipline of statistics in relevant law courses. It is suggested that trial judges operate a checklist to determine whether an expert witness is qualified in a given case. The criminal justice system has a huge task of exposing true child abusers. But not at the expense of convicting the innocent. The social cost of wrongful conviction of accused parents in sudden infant death cases is immense. In punishing an innocent person a greater error and a worse 'moral harm' would have been inflicted than not punishing a guilty person. Families and friends of wrongly convicted parents tend to suffer immense distress and emotional harm. And such wrongful convictions could easily cause the disintegration of marriages and families. Tragically Sally Clark never came to terms with her wrongful conviction. In 2007 she drank herself to death. ${ }^{39}$ Equally important elements of the justice system to help achieve that ultimate goal include quality police community investigations, thorough death-scene investigations, quality of autopsy reports, the legal processes and rules of court as well as the competence and representativeness of jurors.

39 http://www.sally Clark/Alcohol killed freed mother Sally Clark - Telegraph.htm 


\section{References}

Adrian Keane, The Modern Law of Evidence (6 $6^{\text {th }}$ edn. Oxford University Press 2006).

Ann Bowling, Research Methods in Health: Investigating health and health services $\left(4^{\text {th }}\right.$ edn. Open University Press Berkshire England 2014)

Margaret Brazier, Medicine, Patients and the Law ( $3^{\text {rd }}$ edn. Penguin Group Ltd 2003).

RW Byard \& HF Krous, Sudden Infant Death Syndrome. Problems, Progress \& Possibilities London: Arnold 2001).

Michael Freeman, Children, medicine and the law (Dartmouth Publishing Ltd 2005).

Robert Hill, Helen Wood, Suzanne Fine, A Practical Guide to Civil Litigation (Bristol, Jordan Publishing Ltd 2003) 241-260.

Phillip I. Good, Applying Statistics in the Courtroom: A new Approach for Attorneys and Expert Witnesses (Chapman \& Hall/CRC 2001).

Carol Jones, Expert witnesses, science, medicine and the practice of law (Oxford Clarendon Press 1994).

Bernard Knight, Legal Practice of Medical Practice ( $3^{\text {rd }}$ edn. Longman Group Ltd 1982).

Andre A. Moenssens, James Starrs, Carol Henderson \& Fred Inbau $\left(4^{\text {th }}\right.$ edn. The Foundation Press, Inc 1995).

Peter Murphy, Murphy on Evidence ( $9^{\text {th }}$ edn Oxford University Press).

Murray Spiegel, Theory and Problems of Statistics (Schaum Series, McGraw Hill Inc 1992)

Michael Stockdale, Criminal and Civil Evidence $\left(6^{\text {th }}\right.$ edn, Northumbria Law Press, Newcastle-Upon -Tyne 2005).

Michael Stockdale \& Christiana McAlhone, The Elements of Evidence ( $6^{\text {th }}$ edn, Northumbria Law Press, Newcastle-Upon -Tyne 1993).

Eugene Volokh, Academic Legal Writing: Law Review Articles, Student Notes and Seminar Papers (New York: Foundation Press 2003). 